This is a preprint version of this manuscript. The final manuscript is:

Kieran Tranter 'Law, the Digital and Time: The Legal Emblems of Doctor Who' (2017) 30(3)

International Journal for the Semiotics of Law 515-532 DOI: 10.1007/s11196-017-9522-0

\title{
Law, the Digital and Time: The Legal Emblems of Doctor Who
}

Dr Kieran Tranter

Associate Professor

Griffith Law School/Law Futures Centre

Griffith University, Gold Coast Australia

Address for Correspondence k.tranter@griffith.edu.au

\section{Abstract}

This article is about time. It is about time, or more precisely, about the absence of time in law's digital future. It is also about time-travelling and the seemingly ever-popular BBC science fiction television series Doctor Who. Further, it is about law's timefullness; about law's pictorial past and the 'visual baroque' of its chronological fused future. Ultimately, it is about a time paradox of seeing time run to a time when time runs 'No More!'

This 'timey-wimey' article is in three parts. The first part looks to a hazy remembered past of the legal emblem tradition as presented in Peter Goodrich's Legal Emblems and the Art of Law to learn visual litercy and also glimps the essential elements of modern legality with authority, decision and violence. The second part maps how these images and icons of modern legality are manifest in the Doctor Who fiftieth year anniversary special 'The Day of the Doctor.' The third stage looks beyond these first order meanings to understand the 
chronological chaos of 'The Day of the Doctor.' The technicity of the image as a portal through time and space that the narrative revolves around charts the implications for the digital end of time for law.

\section{Key Words}

Law, Digital, Time, Doctor Who, Modern legality, obiter depicta.

\section{Introduction}

The present is marked by an epoch changing moment - the transition from paper as the medium of communication to the digital [88]. Modern legality was founded on paper; its possibilities, anxieties and speed were determined by reading, writing, printing, stamping, indexing, copying and filing [97, 71, 91]. Paper was the material condition that made law, as was known, possible. That paper and its technologies are in decline with the coming of the digital is a facile truism of the everyday. However, the implications for legality from this transformation of the material substance through which law happens has been barely thought.

This article attempts to put into focus a particular challenge of the digital for law - the erasure of time. Whereas the paper of modern legality built the archive, an ordering of increasingly yellowing paper that marked a 'past' from which the 'present' could decide the 'future', the digital's pervasiveness of data and code suggest a future that is an ever-present.

Peter Goodrich's recent contribution to law and the visual has been to examine the legal emblem book at the dawn of modernity [34]. Goodrich reflects on a legality that was dealing with the new technologies of paper, print and literacy [27]. The woodblock images that he interrogates with their combination of mundane and esoteric imagery, established a vision of governance at that transitional moment.

This article draws upon Goodrich's strategy of obiter depicta to decode another legality transmogrifying due to technological change. The 2013 fiftieth anniversary special for Doctor Who, aptly titled the 'The Day of the Doctor' [51], presented a cascade of icons and imagery that can been seen as belonging to modern legality. In the show there were excessive 
representations of authority, decision and violence intermeshed with the archive and its signification of linear time.

However, behind these first order meanings, the 'The Day of the Doctor' presented more esoteric knowledge. The key to this was in the technicity of the image. Central to the narrative was the technology of Time Lord art; of the capturing and freezing a segment of time. This image, precisely as an image, dis-ordered the other representations of modern legality. It dis-ordered in a fundamental way by challenging the chronological stability of modern legality. 'The Day of the Doctor' does not reaffirm modern legality but the painting 'Gallifrey Falls No More’ charts the implications for the digital end of time for law.

This argument is in three stages. The first stage reviews Goodrich's strategy of obiter depicta as presented in his 2013 Legal Emblems and the Art of Law to identify a 'method' of visual literacy and also the wellknown elements of modern legality's paper-based existence. The second stage will examine the images and icons of modern legality - of authority, decision, and violence intermeshed with representations of archives - in 'The Day of the Doctor.' The third stage looks beyond these first order meanings to understand the chronological chaos at the heart of 'The Day of the Doctor.' The technicity of the image as a portal through time and space that the narrative revolves around charts the implications of the digital for the time of law.

\section{Obiter Depicta, Image, Icon, Emblem, Law}

Peter Goodrich’s 'obscurely brilliant' [34], 247] treaty on the legal emblem tradition from the 1400-1600 begins in the present. He posits two immediate concerns. The first is the intimate, yet under-articulated, residual of the image within the contemporary practice of law; of law students who know but cannot talk about the images and icons that make law majestic [34]: 1-2]. The second is a wider agenda:

We inhabit an exponentially expanding videosphere, a Planet Hollywood, a YouTube universe, a gamer zone of augmented life in which the public world of digital transmission penetrates almost every crevice of what was formally the private sphere. The modes of the visual that were classically the domain of spiritual government, of the regimen animarum, and specifically of the speculae pastoralis, the spectral watchtowers of the episcopacy, the domain of what are 
now the visual incursions of a pervasively public intimate realm, intrude (or extrude) into all aspects of civil society [34]: 2].

These remarkable sentences knit together a diversity of concerns. It begins by grasping for the anxieties of the digital ('videospheres' and 'gamer zones') whereby the primacy of the image has erased previous proper modes of existence ('the formal private sphere', 'public intimate realm', and 'civil society'). Goodrich then heralds a genealogy. There is the claim that this total governing by the image in the digital has its origins in the emblem tradition; the 'domain of spiritual government' or the 'spectral watchtowers of the episcopacy.' This might be so, and it would take another with a depth of knowledge of emblems and their transmissions to contest Goodrich's claim. However, there is something further in these sentences, which could be seen as Goodrich's justification for the indulgence of his book. These two sentences present a brave alchemy composed of four divergent ingredients.

The first concerns technology as transformative. The second is the primacy of the image, a connection that is essential to the flow of meaning in the sentences yet only partially articulated. The third is the proper place of the image within the art of governance as something old and mostly forgotten, something that needs italic and Latin. This reveals a fourth ingredient, time. The sentences are bookmarked by the present of the twenty-first century and the 'spiritual governance' of the then emergent modernity. These four technology, image, governance and time -form the cypher for Goodrich’s book.

The first - technology - is there within the very reproduction of woodblock images that Goodrich examines. The 'legal emblem book' as he calls it depended on the emergent economy of printing. But it is not what is usually thought of when considering the printing press. The printing press supposedly heralded the empire of words, of literacy, of writing and reading. However, Goodrich focus is the interregnum between the decline of the oral and spectacular and rise of Weber's rational world of writing. The woodblock images are presented in Goodrich's book as transitional technologies, a halfway between the oral and spectacular and the writing of modernity. What is played out, again and again, in Goodrich's exegesis of specific prints, is awareness of the transformative potential of technology. Furthermore, Goodrich has this understanding at the other end of his chronological spectrum. His references to 'Planet Hollywood', 'YouTube universe' and 'gamer zone' seem to roll off the tongue with a sneer. It seems that Goodrich is not pleased by these new forms of living within the digital. What forms of life, beyond greater visual literacy, might be preferable is 
not his focus. However, what is clear is a basic commitment to technology as transformative of life, law and the social.

The second is the image. Goodrich present the neologism of obiter depicta as a supplement to modern legality's tools of textual excavation of ratio decidendi and obiter dicta [34]: 23]. He defines it as 'the study of the visible figures of norm and law, the images internal to the text and also surrounding it in the embodiments and performances that influence advocacy and decision’ [34]: 23]. For Goodrich the image must never be seen as denotive: 'images do not have a single meaning' [34]: 13]. Goodrich's seeing of images is not esoteric; he emphasises that his book is practical in nature. It is about training so that 'lawyers should know the appearance of their profession an should be erudite in the images that they manipulate and transmit' [34]: 11]:

Law is best, which is to say most effective, when it does not have to be stated. If it can simply be present, if it can loom and inhere through signs, through visible manifestations, through a monumental social presence and public array rather than through text and detail, the grimy pain and prolixity of application, then its job is done [34]: 25].

For Goodrich images blur meaning and effect; they are received by an irrational receptor so that meaning 'inheres'. Images are seen and comprehended, although possibly not in the same way by all observers. Most importantly images 'loom', form 'a monumental social presence' that work, not by reading, but by being: 'images excite and ignite, generate fear and hilarity, in ways that prose generally cannot' [34]: 20].

Directly linked in Goodrich's account of images is governance. Images are no mere entertainment, the banal products of Planet Hollywood. Rather, through images law rules. Goodrich mints another neologism to capture this 'visible order of government and law, the visiocracy’ [34]: 16]. Lyndal Sleep and Kieran Tranter in this issue have taken inspiration from 'visiocracy' to chart the governing through encoded icons of the Australian social security mobile app [78]. In Goodrich's book it is the visiocracy of the woodblock images of the emblem tradition that he translates. There is continual representing of the complications and complicities of the relation between the divine and the human, between the written and the manifest, the represented and the unrepresented, the known and unknown, law and justice. Goodrich charts how specific commonplace images of governance - scales, swords, blindfold, crowns and kings - and more obtuse images of doors, gates, flag, sails, windows, 
book, masks, organs, clouds, sphinxes, left hands and empty codices, along with placement and composition, inform of legitimacy, authority, what is right and wrong and what belongs to the temporal or spiritual jurisdiction.

For example the circular emblem reproduced by Goodrich as figure 7.9, titled 'My soul looks upwards ${ }^{1}$ [34]: 229] composed of a foreground heart with an eye, a cloud piercing sun, a city and a hunt. Each image has a specific set of meanings. The city is the 'tellurium realm, the jurisdiction of human law' [34]: 230]. The hunt scene represents the law of nature. The sun a 'heliotropic divinity' pierces the clouds of death to shine its rays onto the seeing heart [34]: 230]. The heart itself, a surreal figure located in the foreground right, possesses the densest meaning. Hearts belong to the interior and are the location of love [34]: 231]. Yet the eye gazes confidently to the viewer, not to the heavens [34]: 230]. This interior organ that sees is faith [34]: 231]. However, Goodrich stresses it is the relations between these images that is the meaning of the emblem. The city is distant in the far left and the hunter, hounds and deer are small in the bottom left. Dividing the two are the rays of the divinity that are absorbed by the posterior of the heart. The heart, the largest image incongruously located in a garden, sees all. The emblem tells of the proper relations of laws. The laws of the city, that is posited law and the laws of nature and unknown radiation of divine law are substantiated in heart:

Tangible things are subtended by incorporeal relations - obligations - and it is through the heart, the apprehension and opening of the affections that the subject will be bound to their proper place and property. Justice is here simply the prior and interior inscription, the institution of the person, the invisible writing of the law of nature on the heart of the individual [34]: 232].

This emblem represents the orders and relations and the sophistication of what later scholars will term the 'natural law tradition.' It is this sense of seeing represented a past legality that is the final cypher for Goodrich’s book: time.

Goodrich's figure 7.9 is timeless. The ordering and relations of the represented species of law is temporally locked. What is being shown are the timeless relations of human, nature and divine laws. The hidden unseen truth made visible. However, this timelessness is not Goodrich's. Time has run its course. Goodrich locates his analysis within a knowing sense

\footnotetext{
${ }^{1}$ Goodrich takes the plate from poet, satirist and pamphleteer George Wither's 1635 collection [100]: 43]. Wither is not the artist responsible for the image. His contribution was English verses to accompany the images produced by Gabriel Rollenhagen.
} 
that the intellectual foundations for law, authority and legal practices has transmogrified from the natural law tradition of early modernity. There is a sense of the passage of time, the erosion of the years on the meaning of images. The city, hunt, astral divinity, clouds and Dali-esque seeing heart picnicking in a garden, still have meaning, but their historical meanings and relations require an adept like Goodrich to transpose. This is the final brave ingredient of Goodrich's book. Each emblem strives to reveal what is truthful and timeless yet the continual feeling for contemporary viewers and readers is the shock of the alienness of the past.

In unravelling Goodrich's book into the strands of technology, image, governance and time, two critical implications can be identified. The first is the method of obiter depicta; of taking seriously images as lawful. The process of decomposition of the whole, the first-order decoding of specific decomposed representations and then reading the relations and revelations from the recomposed whole, will be repeated in the article. Although a 'television event' is not the static icons of the woodblock emblem, Goodrich's process of decomposition and relational recomposition can allow for the untangling of representations and meanings from the baroque succession of audio-visual representations. His book is a studiously worked exemplar of a method of visual literacy.

The second is consideration of the purpose of the emblem tradition. As has been observed the emblem book is a child of Gutenburg. It is print on paper; transient, commercial and material. It was of the world. However, its subject matter was not so frivolous. The emblem book was to teach of things eternal and not seen, to perceive the metaphysics behind the manifest world. It witnessed a legal tradition on the brink of literacy, literalism and positivism. In the very use of the technologies of paper and printing press it anticipates the anxieties of modern legality's paper-based existence. Through the image, the emblem tradition desired to show a changing society, the correct relations between the divine, the natural and the human and the majesty and prudence of properly constituted lawful authority: 'the emblem took the printed text and made it into action' [34]: 263]. By carving and printing at modernity's dawn the emblemists emphasised that the coming legality of words and paper needed a heart that sees. That it needed an intangible sense of justice that could not be taught by the rational process of words alone, but had to be instilled through the emotive affect of the visual. The emblem told the proto-moderns as they rushed towards reformation and nation building, of how to correctly interpret the words that were re-making the world. 
The emblem tradition in its mundane and esoteric imagery can be seen as manifesting the unconscious anxieties of an emergent modern legality operating through paper and words. It furiously printed the need for sovereigns, judges, lawyers and subjects in the 'tellurium realm' to know proper authority and cultivate sound judgment, of a necessary wisdom beyond the words and literal of legal material, else face corruption, destruction, death and violence. In short the emblem tradition captured the essence and anxieties of modern legality in authority, decision and violence.

This is the image that lingers at the end of Goodrich's book. While there is the concluding image of the final pages of the opening of a heart and the living image that 'so escapes from the text, it rises out of the flesh; it is redolent of affect and desires' [34]: 264], the imprint that endures is modern legality and its concerns with authority, decision and violence. There is a shock experienced on leaving Goodrich's account of the emblem tradition and its 'living images' and re-entering the prosaic practices of modern legality. However, it is not that the texts of modern legality are devoid of images. The loss of visual literary within law with the decline of the emblem tradition meant that these images became obvious only in a narrow range of metaphors within legal prose or through a limited array of permissible and regulated icons such as blindfolded justice, sovereign crests or judicial robes. In the repression of the visual, the images and icons of modern legality became broadcasted elsewhere [60]. And it is to this broadcasting that this article turns to Doctor Who and 'The Day of the Doctor.'

\section{3 'The Day of the Doctor', an Emblem of Modern Legality}

Doctor Who is a long-running television science fiction serial by the British Broadcasting Commission (BBC) that began in $1963 .^{2}$ It concerns the ongoing adventures of a bodymorphing, humanoid alien time traveller known only as the 'Doctor.' A member of the species of 'Time Lords', the Doctor travels throughout time and space via his time machine, the TARDIS; which due to a fault in its 'chameleon circuit' is struck looking like a midtwentieth century London police box. Often joined by human (or near-human) 'companions'

\footnotetext{
2 The show was placed in a 'production halt' after the 1989 season and only recommenced as a production by BBC Wales in 2005.
} 
the Doctor saves world, thwarts invasions, defeats monsters, overthrows dictators and rights wrongs, all for the entertainment of a family audience. ${ }^{3}$

In its half-century Doctor Who has become a significant popular cultural icon in its traditional audience markets of the United Kingdom and Australia [18, 67], and since the 2005 has become a global brand [73]. It has introduced into the English language terms like 'Tardis' (meaning something bigger on the inside) [23], 'Dalek', (officiousness bent on extermination) [23], 'behind the sofa' (the cultural phenomena of small children hiding behind lounge-room furniture during a scary scene) [48]. In July 2017 the announcement of Jodie Whittaker as the Thirteenth Doctor was lead news, stage managed by the BBC to be announced at the conclusion of the Wimbledon finale [26]. Doctor Who fandom has been a core research population for the development of fan studies $[94,70]$ and the show was the studied text for the nascent field cultural studies with John Tulloch's and Manuel Alvardo's 1983 Doctor Who: The Unfolding Text [93].

It is Tulloch and Alvardo who possibly explain the open-endedness that has allowed Doctor Who to endure, that it is "an "unfolding text" subtly shifting its ground in response to social and professional pressures, yet vindicating television's recipe for success: something different by something the same' [93]: 3]. The show reinvigorates itself every few years with new actors, aesthetics and especially producers/show runners [12] [89]: 84]. The length of the broadcast duration, across generations of childhoods, has meant that the show regularly engages in nostalgia and drawing upon its own archive, churning out new episodes that are highly inter-textual and playing to a knowing fan audience [19].

The high mark of this tendency to inter-textuality and self-reference are the multi-Doctor anniversary episodes broadcasted in 1973 [66] and 1983 [69]. These episodes celebrate the actors, characters and aesthetics of the show's history, as much as they tell a narrative. The 77 minute fiftieth anniversary special, 'The Day of the Doctor'[51] continues this tradition. Penned by then showrunner Steven Moffat, it was broadcasted simultaneously in 93 countries [42]. The plot, characteristic of many Moffat stories, was convoluted.

In the present day the Eleventh Doctor (Matt Smith) and companion Clara Oswald (Jenna Coleman) are summoned by the alien investigating and invasion repulsing force UNIT to the basement of the National Gallery (the 'Under Gallery') where pictures have been smashed

\footnotetext{
${ }^{3}$ There are many recent book length studies into Doctor Who [18, 38, 47, 55, 79].
} 
from the inside. Also present is a holographic, three-dimensional painting titled either 'Gallifrey Falls' or 'No More' that the Doctor identifies as belonging to his species showing the destruction of the city Arcadia on his home planet Gallifrey in the last stages of the cataclysmic Time War between the Time Lords and the Daleks. On Gallifrey, on the last day of the Time War an earlier previously unscreened regeneration of the Doctor, the 'War Doctor' (John Hurst) has operated an ultimate doomsday weapon devised by the Time Lords, the 'Moment.' A sentient entity, the Moment manifests as a companion of the Ninth and Tenth Doctors Rose Tyler (Billie Piper) and declares if the War Doctor uses the weapon his punishment will be that he, and he alone will survive. As part of this sentence the Moment permits the War Doctor to see the 'man he will become' and is transported to 1562 England where the Tenth Doctor (David Tennant) and Queen Elizabeth I (Joanna Page) are being chased by shapeshifting aliens, the Zygons. The Moment contrives for the Eleventh Doctor to also appear in 1562 England and the three incarnations of the Doctor meet. They uncover that the Zygons, refugees from the Time War, are using a Time Lord 'stasis cube' to construct three-dimensional paintings to hide within to wait for human technology to develop sufficiently to make invading the planet worthwhile. The Doctors thwart the plot and travel back to the present in the Tenth Doctor's TARDIS. In the present the Zygons from the smashed paintings have infiltrated UNIT's secret repository of alien technology the 'Black Archive' located under the Tower of London. UNIT's leader Kate Stewart (Jemma Redgrave) instigates a count-down for a nuclear bomb, a failsafe to destroy the archive and London to prevent the technology falling into the wrong hands, claws or plungers. Unable to materialise the TARDIS in the Black Archive, the Doctors use the stasis cube to jump into the named painting 'Gallifrey Falls' or 'No More' that had been relocated to the Black Archive, and smash out into the Black Archive.

The Tenth and Eleventh Doctor trigger a memory suppression field so that the Zygon and human antagonists forget which species they belong to. This forces a shutdown of the countdown and the negotiation of a treaty allowing the Zygons to integrate peacefully into human society. The War Doctor, seeing the men he will become and the 'worlds that his regret will save' [51], indicates to the Moment that he is ready to trigger the device. Back on Gallifrey the Moment has transformed into a 'Big Red Button', but the War Doctor is prevented from going through by the arrival of the Tenth and Eleventh Doctors. They hatch a plan to use their TARDIS to shift Gallifrey to a 'pocket universe' and calling upon all of their 
generations, including the then forthcoming Twelfth Doctor (Peter Capaldi) to seemingly 'save’ Gallifrey while the Dalek ships destroy each other in cross fire.

Returning to the present, the War Doctor and Tenth Doctor say farewell to the Eleventh noting that they will not remember that they saved Gallifrey rather believing that they had triggered the device and committed genocide of the Time Lords, if not the Daleks. ${ }^{4}$ The Eleventh Doctor is left looking at the picture and is joined by the 'Curator' (Tom Baker), who has an uncanny likeness to an aged Fourth Doctor, and explains that the painting previous two names are one, its full title is 'Gallifrey Falls No More'.

What is immediately obvious from the multi-planet, multi-time run-around that is 'The Day of the Doctor' is the proliferation of images and icons that belong to modern legality. Doctor Who is not known for its high levels of 'law in literature' representations of law and lawyering; although the Doctor has been tried by the Time Lords on two occasions ${ }^{5}$ and the Doctors' TARDISes are various interpretations of a police box. In 'The Day of the Doctor' the memory wiping precondition to a 'just agreement' between Humans and Zygons is one of the clearest televisual representations of John Rawls' 'veil of ignorance' leading to justice as fairness [74]. There are images of law in the wax and parchment of Queen Elizabeth I's writ of appointment of the Doctor as curator of the Under Gallery, in the police holding curious crowds back outside the National Gallery and in the dark gloom of Elizabethan law and order of the Doctors being locked in the Tower of London.

Foremost, authority was on show. The Doctor, and 'The Day of the Doctor' has three of them, exudes authority. A continual critique of the show with its titular Time Lord lead character is its materialising of a particular vision of male, scientific and English social class confidence in command [16, 36]. The standard structure of a Doctor Who episode is the Doctor taking command, organising, planning and manipulating. In 'The Day of the Doctor' the War Doctor takes the authority to use the Moment, the Tenth Doctor is revelled to be the secret husband, and King of England, to Elizabeth I, while the Eleventh Doctor has UNIT operatives doing what he says. The Doctors wave their sonic screwdrivers and lessor entities obey. In 'The Day of the Doctor', the Doctor is shown to be the ultimately authority and

\footnotetext{
${ }^{4}$ That the Daleks survived their supposed destruction along with Gallifrey was a continual theme in Doctor Who episodes with the Ninth (Christopher Eccleston), Tenth and Eleventh Doctor facing the old enemy [50, 37, 40, $41,81,82,4,3,5]$.

5 The Second Doctor in 'The War Games' [65] and the Sixth Doctor in the 1986 season long arc 'Trial of a Time Lord' [21, 63, 62, 64]. On the absence of 'law properly called' signifiers in Doctor Who see [92]: chapter $6]$.
} 
other authorities - whether the under-siege leaders on Gallifrey, or Kate Stewart as leader of UNIT, the Zygon commander, or Elizabeth I - do as they are told.

This authority is revealed to have a purpose - to make decision. There is something deeply jurisprudential on show in 'The Day of the Doctor.' Whether through Robert Cover [22], Jacques Derrida [24], Carl Schmitt [75] or Giorgio Agamben [1], modern legality has demanded the necessity of an embodied decision-maker that determines life or death, normal or exception. Indeed, the episode is structured around the ultimate in terrible decisions; the decision to use the Moment to terminate the Time War by committing genocide of both the Time Lords and Daleks. This 'history' had entered Doctor Who mythos in 2005 with the relaunch of the series [29] and the Ninth and Tenth Doctors were particularly characterised by a sense of survivors guilt and shame [20, 8]. 'The Day of the Doctor' shows the weight of taking on decision and for fans, always slightly concerned that their hero had committed genocide, a seeing that another decision was actually made; that the Doctors chose not to and found an alternative way to save Gallifrey and destroy the Daleks.

That violence is also represented in 'The Day of the Doctor' is also not surprising. Doctor Who has been screening death and destruction into living-rooms since the 1960s. Indeed, it is a very rare episode that does not contain physical violence, death scenes and images of corpses [35]. This is, after-all, a show that features as some of its more famous episode titles 'City of Death' [43] 'Robots of Death' [15] 'The Green Death' [10] and 'Death in Heaven' [85]. A significant portion of the budget was spent, in a nod to science fiction film tropes, on showing the defending soldiers and civilian population of Arcadia losing to the Dalek onslaught. There is discussion of the ' 2.47 billon children' [51] supposedly killed when the Doctor used the Moment to end the Time War. There is physical conflict between the human UNIT operative Osgood (Ingrid Oliver) and her Zygon clone. And there are threats of violence, threats to harm individuals if they do not comply with barked Zygon commands, threats to blow up London, Dalek cries of exterminate and shadowing all the violence of an ultimate terrible decision to use the Moment.

As a composition, 'The Day of the Doctor' shows the collocating of authority, decision and violence as the indivisible trinity of modern legality. Each presupposes the other. Authority comes from accepting the decision to do violence. However, 'The Day of the Doctor' does not just present modern legality's tripartite essence it also interposed them with representations of archives. This occurs at two levels. The first were the intra-textual archives 
of the Under Gallery and the Black Archives. These showed a particular arrangement, an ordering and a safekeeping of material things over time. Awareness of its materiality within the archive has come late to modern legality [97, 91]. The archive is a physical repository, a storehouse, but it is something more. It has logic and a memorialisation; hence its attraction as a metaphor for both Sigmund Freud [25]: 15-16] and Michel Foucault [2]: 143]. Like one of Goodrich's emblems there is more to the archive than the sum of its parts, rather it is the relation between the parts, the capacity to identify and locate and to put a part into a relation with others and the whole that is the genius of the archive. The archive is not just a collection of things that accumulates over time but is a material ordering through time [25]: 2]. This material ordering through time is exceptionally obvious in the inter-textuality to the received archive of the Who-verse that is manifest in 'The Day of the Doctor.' The show, 'wheezes and groans', using the description of the TARDIS materialising ${ }^{6}$, under a patchwork of inreferences and fan pleasing asides. From the black and white image of a policeman walking past a sign for 'I. M. Foreman', the scrapyard that the First Doctor in the premiere episode 'The Unearthly Child' [52] hid the TARDIS in, to the photographs of past companions and bits and pieces from past friends and foes in the Black Archive, to the return of the Zygons last seen in 1975 [17], to the cameo by Tom Baker who played the Fourth Doctor as the Curator. This manifesting the archive was also evident in the dialogue with classic lines like 'reverse the polarity ${ }^{7}$, 'you've redecorated, I don't like it' ${ }^{8}$, 'timey-wimey' ${ }^{9}$ and the Tenth Doctor repeating his farewell line 'I don't want to go' from 'The End of Time' [30]. The past of Doctor Who was bought to the present.

The intra and inter-textual representations of archives provides a further interrogation of 'The Day of the Doctor' as an emblem of modern legality. It presents that authority, decision and violence exists in time; that there is an external linearity to the chronology of modern legality. ${ }^{10}$ Archives memorialise through time; they grow, threatening to overwhelm the

\footnotetext{
${ }^{6}$ A phrase used by the Moment in 'The Day of the Doctor' to describe the arrival of the Tenth and Eleventh Doctors' TARDIS but commonly associated in novelisations of Doctor Who scripts by Terrance Dick in the 1970s and 1980s.

7 The full phrase 'reverse the polarity of the neutron flow' is popularly associated with the Third Doctor (Jon Pertwee), although only uttered by him in one episode [9].

${ }^{8}$ Said by the Second Doctor to the Third Doctor in 'The Three Doctors' [66].

9 'Timey-wimey’ formed part of the Tenth Doctor's speech in Steven Moffat scripted 2007 episode 'Blink’ [59]. The full quote is:

People assume that time is a strict progression of cause to effect, but actually, from a non-linear, non-subjective viewpoint, it's more like a big ball of wibbly-wobbly timey-wimey stuff. It has become something of a aca-fan catchcry, see [98] [96] [54]

${ }^{10}$ [87], 180] See also [92] chapter 3.
} 
physical space and the ordering of the registry system [97]: 91-96]. A fundamental key to the archive is time itself: dates of creation, issuing and archiving are recorded on the item. The calendar as an ordering of linear time is used as an entropic resistant key. Unlike the timelessness that the emblem tradition attempted to reveal through their prints, modern legality is absolutely wielded to time [101]: 213]. At an essential level time is the shared commonality within positivist accounts of law [28]: 17]. The practice of modern legality involves an intimacy with the calendar; as a continuous barrage of limitations, sentences, court dates, appointments, billable hours are needed to be calculated [32]: 664-665]. Authority, decision and violence occur in a present, a Moment, but emanate from a past and go to make the future.

In many respects 'The Day of the Doctor' as obiter depicta of modern legality, as authority, decision and time bound in linear time, is not remarkable. Indeed, the same set of images, arrangements and meanings can be glimpsed within other Doctor Who episodes. For example the 'The Creature from the Pit' from 1979 [7], an episode made infamous by the eponymous monster's resembling a giant glowing green erect penis and by John Fiske’s devastating 1983 critical review essay [31]. There are many representations of authority, decision and violence wrapped up in a linear story of the Fourth Doctor, companion Romana (Lalla Ward) and robot dog K9 arriving in the TARDIS, unravelling the mystery of the creature (an nonhumanoid telepathic alien diplomat), righting wrongs, facilitating regime change and preventing an interplanetary war, before leaving again. Although a time machine and time travel has been essential to the meta-structure of Doctor Who, most of the Doctor's screened activities have been 'adventures in time’ [90]: 224], to adopt Stanislaw Lem’s phrase from his 1970 paper 'The Time Travel Story and Related Matters of Science-Fiction Structuring' [56].

However, 'The Day of the Doctor' possesses significant supplements to the temporal linearity of 'The Creature from the Pit.' There is much of Moffat's signature prioritising of timetravelling on show $[11,89]$; TARDISes fly through Earth's and Gallifrey's history, the Moment creates time tunnels for Doctors to leap through, Clara Oswald uses a 'vortex manipulator' to escape the Zygons and join the Doctors in 1562. The Doctors seemingly 'rewrite' the ending of the Time War. The representations of linear time are disrupted by images and icons that suggest flux. It is particularly the supplement of the image itself - the stasis cube produced picture of 'Gallifrey Falls No More' - that unlocks an alternative message about law within 'The Day of the Doctor.' 


\section{The Temporal Technicity of the Image}

In Goodrich's examination of the emblem tradition he identified layers of meanings within emblems. There were often first-order meanings, the meanings that come easiest to a seeing eye. These meanings, formed by well-known images and associations were meant for a wider audience: commonplace messages for the commoners. However, there were also more cryptic meanings to be identified through closer examination of the image, its composition and the use of more arcane signs and relationships. These images within images, meanings within meanings, were for the adept and might deepen, challenge or invert the first-order meaning.

'The Day of the Doctor' with its representation of authority, decision and violence interlaced with the archive as a representation of linear time, strongly denotes modern legality. However, there are the acknowledged unsettling surpluses of time in the screened time travelling. 'The Day of the Doctor' can be understood as about modern legality, but it is also about time.

The nexus for the show's interrogation with time is the image. Central to the narrative is the image 'Gallifrey Falls No More.' However, it is not presented as an object but rather a process. What is important about 'Gallifrey Falls No More' is not the secret of its name, but rather that it is a product of a technical process. As described by the War Doctor: 'It's not a picture, it's a stasis cube. Time Lord art. Frozen instants in time, bigger on the inside' [51]. A double association is projected. First, the image is linked directly to technicity [44]. The second is a postulation regarding time as technologically mediated [80]. The fantastic claims regarding Time Lord art creating bigger on the inside frozen instants in time, mirrors a general truism about technology. Technology, is developed, purchased and consumed on the promise that it saves time. Whether that is true in an empirical sense for every new process or gizmo that hypercapitalism generates for its 'producer-consumers' [76] is beside the point. What is the point is that time is technology's domain; whether that is the speed of the motor car, the productivity of the factory, the instant communication of televisual broadcasting, or the mnemonic capacity of the archive. Technology dis-orders time.

It is this dis-ordering of linear time that is shown in 'The Day of the Doctor' notwithstanding its first-order representing of archives as linear time. Lem criticises 'adventure in time' stories like 'The Creature from the Pit' as failing to deal with the problems of 'paradoxes' $[61,57]$ that come from disrupting linear time of cause and effect in science fiction's time 
travel stories [56]: 138-144]. For Lem the 'fun' of time travel stories 'consists in the way the paradox is shifted from one segment of action to another.' [56]: 144]. Lem identifies two 'authorial attitudes' in science fiction towards paradoxes, either embracing the illogicality often through humour, or strategies that 'cleverly avoid them.' [56]: 145]. The paradox in 'The Day of the Doctor', as in other multi-Doctor episodes, is that the numerically older Doctor should remember the adventure: the Eleventh Doctor is in a present that he is sharing with his past incarnations. Moffat knowingly played on this in the mini-episode 'Time Crash' [39] where the Tenth Doctor saved the Fifth Doctor (Peter Davison) by 'remembering' what he saw the Tenth Doctor doing when he was the Fifth Doctor. In 'Time Crash' Moffat manifests one of Lem's authorial attitudes, an embrace of the illogicality through humour, a strategy repeated in 'The Day of the Doctor' in the witty banter between the Doctors. 'The Day of the Doctor' also evidences another authorial attitude that minimised the disruption of the paradox on the narrative. There was the claim that younger Doctors will not remember that they saved, rather than destroyed Gallifrey because 'the time streams are out of sync' [51].

What is important is that the critical narrative device involved a representation of technology, image and time. The Zygon invasion, the Doctors scheme to enter the Black Archive, and the ultimate plan to save Gallifrey from the Daleks, involved representations of technology 'freezing' time. In the emblem tradition the image was timelessness; there was an attempt to represent the eternal beyond the materiality of the world and its increasing reliance on the word. In 'The Day of the Doctor' the representations of linear time are interrupted by technically frozen time.

The Western tradition of time has tended towards a cleaved debate. For Plato time was a property of becoming; for in the metaphysical realm there is no time, just existence [72]: 5152 (37-38)]. In Augustine, Plato’s notion of time verse eternity, related to God verse man, with the soul the site for the experience of time [58]: 15]; the base theological structure of the legal emblem tradition. In the alternative, Aristotle posits time as a succession of now-events; The past was the now, while the future is the now-to-come [6], 369-378 (218 $\left.{ }^{\mathrm{a}}-224^{\mathrm{a}}\right)$. Much of the philosophic exploration of time remains locked into these perimeters. J. M. E. McTaggart's 1908 essay gave the uninspiring terms A-series and B-series to the two metaaccounts of time [33]: 66] The A-series presents time as tensed, bodies move through time. Within the A-series, it is sensible to talk of the experience of time passing [68], 11 (307)]. The B-series is without tense [68]: 10 (306)]. Events are described as earlier, later or 
simultaneous [13]: 3]. A-series time is subjective; while B-series time is objective. For Martin Heidegger the Western tradition on time, with its A and B-series was 'vulgar' [53]: 45-46], it missed the specificities of being-in-time [45]: 217 (235)]. Heidegger’s Being exists across times, while simultaneously can only but be in a linear time that ends in death [45]: 384 (419)]. It has been suggested that the Doctor's timelessness and timefullness can be seen as grounding an embodied ethic that emanates from this more unitary and experiential account of time [89], a being 'resolute' [45]: 274 (298) in the present and grasping the unity of the three temporal dimensions - the 'ecstases' [45]: 321 (350)] - as the ground for free action [99]: 107-108].

However, A-series, B-series, and Heidegger's mastering of the ecstases is not what is happening in 'The Day of the Doctor' with the image that is a 'slice of real time, frozen' [51]. In all, order is presupposed; either the subjective experience of the flow of time, or the objective relations of the calendar, or the resolutely ordering past, present and future to be authentic within a ‘thrown' world [45]: 227-231 (245-249)]. There is a necessary sense of structure between past, present and future. Modern legality, with its chronologies, calendars and time awareness was full of structured time. However, the transition to the digital is witnessing a changed relationship to time. Modern legality's paper-based existence was slow, its processes took time as documents were drafted, sent, signed, filed, stamped. Information technologies of paper meant that the moment of decision where authority and violence in an immediate present ordered the past to declare a future left a material trace. These traces formed the 'Great Archive' of law, a memorisation of the past in reams and folders of yellowing paper [91].

However, at essence the digital leaves no material trace. Like the legal emblemists witnessing a changing mode of information from the oral to the written, the present is witnessing the transition from the written to the digital. In the digital writing need not hold sway, and humans need not decide. Rather data, code, sensors, AI and robots are beginning to occupy much of what modern legality regarded as law and its practices [83, 84]. There is a growing governance purely through images, epitomised by the interactive icons on smart devices [88, 78]. It is the emergence, or more properly, re-emergence of governance by the image that orientated Goodrich's study. While the emblem tradition was anxious for modern legality to know the timelessness of proper authority and sound judgment, what the frozen time image of 'Gallifray Falls No More' from 'The Day of the Doctor' highlights is the anxiety of the end of time in law's digital future. 
The digital does not require the archive. The digital can be programed to archive; but this is not as inherent to the art of governing as it was with modern legality. The digital with its speed and immediacy, with its constant information flows and with its automation, presents a hyper-present. Without an archive through which to remember and reflect on, the past, so tangible and present in the materiality of modern legality, becomes diffuse and subjective. It becomes soft and organic as it retreats back inside human skulls. Further, the automation of the digital increasingly relieves the consumer-producers of the present the need to exercise the faculty of 'prudence': the 'presumption of the future contracted from the experience of past time' [49], 13, italics in original]. The spaces for human decision, for responsibility towards the future, whether that is in relation to jurisprudence, the deployment of lawful violence, or merely the prudence of self-care and planning, are in retreat. The digital is increasingly automating legal decisions [46, 77], and robots are starting to drive cars [95, 86]. The future is becoming less enmeshed with the experience of the human present. The digital suggests a future without either a past or a future; an only now of bits and bytes that is a temporal monolith of the present.

The implications that arise from the temporal reconfiguration accompanying the transition from paper to the digital is a challenging - and from the standpoint of modern legality, terrifying alien - 'digital legality' [71, 91]. This is the final paradox manifest in 'The Day of the Doctor.' It is a paradox of seeing time run to a time when time runs, to quote the War Doctor, 'No More!'[51]. Digital legality suggests a timeless visual law where law and act become absolutely fused. Authority, decision and violence manifest simultaneously and have become frozen in algorithms and code. Modern legality humanised law. By locating law in time and at the loci of human decision: 'Law then becomes reducible to two features: policy choices and techniques of implementation. Our questions are "What do we want?" and "How do we get it?”' [14], 686]. Implicit in this quote from James Boyd White is identification of the tendency to technicity in modern legality that has possibly given impetus to the digitalisation of law. Yet his 'we' emphasises a human orientated legality. Modern legality for all its faults was built by humans over time, and held within it the promise that it could be reformed by humans over time.

In 'The Day of the Doctor' the Doctor(s) master time through technologies; TARDISes, the Moment and stasis cubes. As an emblem of law, the episode showed the elements of modern legality; of authority, decision, violence and linear time. It also showed the dis-ordering of 
linear time by the visual and digital. It glimpses a potential future that has become chronologically fused. It also suggests in the Doctors' triumph that significant thinking and planning and acting through technologies will be needed to keep time flowing in law's digital future. The future is not fate; but the present, more urgently than ever, needs to be active in envisioning the architecture, algorithms and programs of digital legality that humans will want to live resolutely within.

\section{Conclusion}

This article argued that the fiftieth anniversary special for Doctor Who, 'The Day of the Doctor' [51] is a timely emblem for law in the present. Drawing upon Goodrich's examination of the legal emblem tradition and his notion of obiter depicta it was shown that the show manifested the essential elements of modern legality in authority, decision, violence and linear time. It was also shown that the technicity of the image dis-ordered the temporal certainty of modern legality. Glimpsed within the BBC's celebratory and self-referential 'timey-wimey’ romp is an inhuman future of a chronologically frozen digital legality. Finally, 'The Day of the Doctor' as an emblem of legality in transition from paper to the digital, suggests that engagement with the processes of technical transformation in the present is essential to mould a more desirable human future.

\section{References}

1. Agamben, Giorgio. 1998. Homo Sacer: Sovereign Power and Bare Life. Trans. Daniel Heller-Roazen. Crossing Aesthetics. Stanford: Stanford University Press.

2. Agamben, Giorgio. 2002. Remnants of Auschwitz: The Witness and the Archive. Trans. Daniel Heller-Roazen. New York: Zone Books.

3. Ahearne, Joe. 2005. Bad Wolf. Doctor Who. 11 June 2005. United Kingdom: BBC.

4. Ahearne, Joe. 2005. Dalek. Doctor Who. 30 April 2005. United Kingdom: BBC.

5. Ahearne, Joe. 2005. The Parting of the Ways. Doctor Who. 18 June 2005. United Kingdom: BBC.

6. Aristotle. 1984. Physics. In The Complete Works of Aristotle: The Revised Oxford Translation, ed. Jonathan Barnes, 315-446. Princeton, New Jersey: Princeton University Press.

7. Barry, Christopher. 1979. The Creature from the Pit. Doctor Who. 27 October - 17 November 1979. United Kingdom: BBC.

8. Beattie, Melissa. 2010. Life During Wartime: A Analysis of Wartime Morality in Doctor Who. In The Mythological Dimensions of Doctor Who, eds. Anthony Burdge, and Jessica Burke, and Kristine Larson, 85-104. Cawfordville: Kitsune Books. 
9. Bernard, Paul. 1972. The Sea Devils. Doctor Who. 26 Feburary - 1 April 1972. United Kingdom: BBC.

10. Bernard, Paul. 1973. The Green Death. Doctor Who. 19 May - 23 June 1973. United Kingdom: BBC.

11. Booth, Paul. 2013. Effecting the Cause: Time Travel Narratives. In Doctor Who In Time and Space, ed. Gillian Leitch, 97-111. Jefferson, North Carolina: McFarland.

12. Booth, Paul. 2014. Periodising Doctor Who. Science Fiction Film and Television 7 (2):195-215.

13. Bourne, Craig. 2006. A Future for Presentism. Oxford: Clarendon Press.

14. Boyd White, James. 1985. Law as Rhetoric, Rhetoric as Law: The Arts of Cultural and Communal Life. University of Chicago Law Review 52 (3):684-702.

15. Briant, Michael E. 1977. The Robots of Death. Doctor Who. 29 January - 19 Feburary 1977. United Kingdom: BBC.

16. Brown, J P C. 2011. Doctor Who: A Very British Alien. In The Galaxy is Rated G: Essays on Children's Science Fiction Film and Television, eds. R C Neighbors, and Sandy Rankin, 161182. Jefferson, North Carolina: McFarland and Company.

17. Camfield, Douglas. 1975. Terror of the Zygons. Doctor Who. 20 August - 20 September 1975. United Kingdom: BBC.

18. Chapman, James. 2006. Inside the TARDIS: The Worlds of Doctor Who A Cultural History. London: I B Tauris.

19. Chapman, James. 2014. Fifty Years in the TARDIS: The Historical Moments of Doctor Who. Critical Studies in Television 9 (1):43-57.

20. Charles, Alec. 2008. War Without End?: The Family, and the Post-9/11 World in Russell T. Davies's Doctor Who. Science-Fiction Studies 35 (3):450-465.

21. Clough, Chris. 1986. The Ultimate Foe. Doctor Who. 29 November - 6 December 1986. United Kingdom: BBC.

22. Cover, Robert M. 1986. Violence and the Word. Yale Law Journal 95 (8):1601-1630.

23. Cull, Nicholas J. 2001. "Bigger on the Inside...": Doctor Who as British Cultural History. In The Historian, Television and Television History, eds. Graham Roberts, and Philip M Taylor, 95111. Luton: University of Luton Press.

24. Derrida, Jacques. 1992. Force of Law: The "Mystical Foundations of Authority". In Deconstruction and the Possibility of Justice, eds. Drucilla Cornell, and Michel Rogerfield, and David Grey Carlson, 3-67. New York: Routledge.

25. Derrida, Jacques. 1995. Archive Fever: A Freudian Impression. Trans. Eric Prenowitz. Religion and Postmodernism. Chicago: University of Chicago Press.

26. Doctor Who: BBC Announces Jodie Whittaker as First Female Doctor in Sci-Fi Series' 54 Year History. 2017. ABC News. http://www.abc.net.au/news/2017-07-17/doctor-who-jodiewhittaker-named-first-female-doctor/8713964. Accessed 8 August 2017.

27. Douzinas, Costas, Ronnie Warrington, and Shaun McVeigh. 1991. Postmodern Jurisprudence: The Law of Texts and the Text of Law. London: Routledge.

28. Dworkin, Ronald. 1977. Taking Rights Seriously. Cambridge, Massachusetts: Harvard University Press.

29. Euros, Lyn. 2005. The End of the World. Doctor Who. 2 April 2005. United Kingdom: BBC.

30. Euros, Lyn. 2009/2010. The End of Time. Doctor Who 25 December and 1 January 2009/2010. United Kingdom: BBC.

31. Fiske, John. 1983. Doctor Who: Ideology and the Reading of a Popular Narrative Text. Australian Journal of Screen Theory 14-15:69-100.

32. French, Rebecca R. 2001. Time in Law. University of Colorado Law Review 72 (3):663-748.

33. Gale, Richard M. 1968. The Static Versus the Dynamtic Temporal. In The Philosophy of Time: A Collection of Essays, ed. Richard M Gale, 65-84. New Jersey: Humanities Press.

34. Goodrich, Peter. 2013. Legal Emblems and the Art of Law: Obiter Depicta as the Vision of Government. Cambridge: Cambridge University Press. 
35. Green, Melody. 2010. "It Turns Out They Died For Nothing": Doctor Who and the Idea of a Sacrifical Death. In The Mythological Dimensions of Doctor Who, eds. Anthony Burdge, and Jessica Burke, and Kristine Larson, 105-119. Cawfordville: Kitsune Books.

36. Gregg, Peter R. 2004. England Looks to the Future: The Cultural Forum Model and Doctor Who. Journal of Popular Culture 37 (4):648-661.

37. Gunn, Andrew. 2010. Victory of the Daleks. Doctor Who. 7 April 2010. United Kingdom: BBC.

38. Harmes, Marcus K. 2014. Doctor Who and the Art of Adaption: Fifty Years of Storytelling. Lanham: Rowan and Littlefield.

39. Harper, Graeme. 2007. Tim Crash. Doctor Who. 16 November 2007. United Kingdom: BBC.

40. Harper, Graeme. 2008. Journey's End. Doctor Who 5 July 2008. United Kingdom: BBC.

41. Harper, Graeme. 2008. The Stolen Earth. Doctor Who 28 June 2008. United Kingdom: BBC.

42. Harris, Jamie. 2013. Doctor Who' 50th Anniversary to be Simulcast Worldwide to Avoid Leaks. Digital Spy. http://www.digitalspy.com/tv/doctor-who/news/a501432/doctor-who-50thanniversary-to-be-simulcast-worldwide-to-avoid-leaks/. Accessed 7 August 2017.

43. Hayes, Michael. 1979. City of Death. Doctor Who. 29 September - 20 October 1979. United Kingdom: BBC.

44. Heidegger, Martin. 1977. The Age of World Picture. In The Question Concerning Technology and Other Essays, 115-154. New York: Harper \& Row.

45. Heidegger, Martin. 1996. Being and Time. Trans. Joan Stambaugh. New York: State University of New York Press.

46. Henman, Paul. 2010. Governing Electronically: E-Government and the Reconfiguration of Public Administration, Policy, and Power 2010. Houndmills, Basingstoke: Palgrave Macmillan.

47. Hills, Matt. 2010. Triumph of a Time Lord: Regenerating Doctor Who in the Twenty-First Century. London: I B Tauris.

48. Hills, Matt. 2011. Listening From Behind the Sofa? The (Un)earthly Roles of Sound in BBC Wales' Doctor Who. New Review of Film and Television Studies 9 (1):28-41. doi:10.1080/17400309.2011.521716.

49. Hobbes, Thomas. 1651/2008. Leviathan. New York: Pearson Longman.

50. Hurran, Nick. 2012. Asylum of the Daleks. Doctor Who. 1 September 2012. United Kingdom: BBC.

51. Hurran, Nick. 2013. The Day of the Doctor. Doctor Who. 23 November 2013. United Kingdom: BBC.

52. Hussein, Waris. 1963. The Unearthly Child. Doctor Who. 23 November - 14 December 1963. United Kingdom: BBC.

53. Keller, Pierre. 1996. Heidegger's Critique of the Vulgar Notion of Time. International Journal of Philosophical Studies 4 (1):43-66.

54. Larsen, K. 2014. "Wibbly-Wobbly, Timey-Wimey-Stuff:"Teaching with a Time Lord. In Ensuring Stem Literacy: A National Conference on STEM Education and Public Outreach.

55. Layton, David. 2012. The Humanism of Doctor Who: A Critical Study in Science Fiction and Philosophy. Jefferson, North Carolina: McFarland.

56. Lem, Stanislaw. 1985. The Time Travel Story and Related Matters of Science-Fiction Structuring. In Microworlds: Writings on Science Fiction and Fantasy, 136-160. London: Secker and Warburg.

57. Lewis, David. 1976. The Paradoxes of Time Travel. American Philosophical Quarterly 13 (2):145152.

58. Lloyd, Genevieve. 1993. Being in Time: Selves and Narrators in Philosophy and Literature. London: Routledge.

59. MacDonald, Hettie. 2007. Blink. Doctor Who 9 June 2007. United Kingdom: BBC.

60. MacNeil, William P. 2007. Lex Populi: The Jurisprudence of Popular Culture. Stanford: Stanford University Press.

61. Malament, David B. 1984. "Time Travel" in the Gödel Universe. PSA: Proceedings of the Biennial Meeting of the Philosophy of Science Association (2):91-100. 
62. Mallett, Nicholas. 1986. Mindwarp. Doctor Who. 4 - 25 October 1986. United Kingdom: BBC.

63. Mallett, Nicholas. 1986. The Mysterious Planet. Doctor Who. 6 - 27 September 1986. United Kingdom: BBC.

64. Mallett, Nicholas. 1986. Terror of the Vervoids. Doctor Who. 1 - 22 November 1986. United Kingdom: BBC.

65. Maloney, David. 1969. The War Games. Doctor Who. 19 April - 21 June 1969. United Kingdom: $\mathrm{BBC}$.

66. Mayne, Lennie. 1972/1973. The Three Doctors. Doctor Who. 30 December - 20 January 1972/1973. United Kingdom: BBC.

67. McKee, Alan. 2009. Is Doctor Who Australia. Media International Australia (132):54-66.

68. McTaggart, John Ellis. 1927. The Nature of Existence. Cambridge: Cambridge University Press.

69. Moffatt, Peter. 1983. The Five Doctors. Doctor Who. 25 November 1983. United Kingdom: BBC.

70. O'Day, Andrew. 2013. Social Spaces: British Fandon to the Present. In Doctor Who In Time and Space, ed. Gillian Leitch, 25-43. Jefferson, North Carolina: McFarland.

71. Pearson, Ashely, and Kieran Tranter. 2015. Code, Nintendo's Super Mario and Digital Legality. International Journal for the Semiotics of Law 28 (4):825-842. doi:10.1007/s11196-015-9417$\mathrm{x}$.

72. Plato. 1965. Timaeus and Critias. Trans. Desmond Lee. London: Penguin.

73. Porter, Lynnette. 2012. The Doctor Who Franchise: American Influence, Fan Culture and the Spinoffs. Jefferson, North Carolina: McFarland.

74. Rawls, John. 1971. A Theory of Justice. Oxford: Oxford University Press.

75. Schmitt, Carl. 1996. The Concept of the Political. Trans. George Schwab. Chicago: University of Chicago Press.

76. Shum, Annie, and Kieran Tranter. Seeing, Moving, Catching, Accumulating: Pokémon GO, and the Legal Subject. International Journal for the Semiotics of Law 30 (3). doi:10.1007/s11196-0179519-8.

77. Simpson, Brian. 2016. Algorithms or Advocacy: Does the Legal Profession Have a Future in a Digital World. Information and Communications Technology Law 25 (1):50-61.

78. Sleep, Lyndal, and Kieran Tranter. 2017. The Visiocracy of the Social Security Mobile App in Australia. International Journal for the Semiotics of Law 30 (3). doi:doi:10.1007/s11196-0169498-1.

79. Sleight, Graham. 2012. The Doctor's Monsters: Meaning of the Monstrous in Doctor Who. London: I B Tauris.

80. Stiegler, Bernard. 1998. Technics and Time, 1: The Fault of Epimetheus. Trans. Richard Beardsworth. Stanford: Stanford University Press.

81. Strong, James. 2007. Daleks in Manhattan. Doctor Who 21 April 2007. United Kingdom: BBC.

82. Strong, James. 2007. Evolution of the Daleks. Doctor Who 28 April 2007. United Kingdom: BBC.

83. Susskind, Richard. 2013. Tomorrow's Lawyers: An Introduction to Your Future. Oxford: Oxford University Press.

84. Susskind, Richard, and Daniel Susskind. 2015. The Future of the Professions: How Technology Will Transform the Work of Human Experts. Oxford: Oxford University Press.

85. Talalay, Rachel. 2014. Death in Heaven. Doctor Who. 8 November 2014. United Kingdom: BBC.

86. Thierer, Adam, and Ryan Hagemann. 2015. Removing Roadblocks to Intelligent Vehicles and Driverless Cars. Wake Forest Journal of Law \& Policy 5 (2):339-392.

87. Tontii, Jarkko. 2004. Right and Prejudice: Prolegomena to a Hermeneutical Philosophy of Law. Aldershot: Ashgate.

88. Tranter, Kieran. 2012. "Come a Day there Won't be Room for Naughty Men Like Us to Slip About at All": the Multi-Medium Outlaws of Serenity and the Possibilities of Post-Literate Justice. Law Text Culture 16:277-304.

89. Tranter, Kieran. 2013. In and Out of Time: Memory and Chronology of Doctor Who. In Doctor Who In Time and Space, ed. Gillian Leitch, 82-96. Jefferson, North Carolina: McFarland. 
90. Tranter, Kieran. 2015. Narrative and Paradoxes in Doctor Who "Time Loop" Stories. In The Past from the Present, The Future from the Past: Television Explores Time Travel, London, eds. Sherry Ginn, and Gillian Leitch, 223-232. London: Rowman and Littlefield.

91. Tranter, Kieran. 2017. I, Archive: Envisioning and Programming Digital Legality from SyFy's Caprica. In Envisioning Legality: Law, Culture and Representation, eds. Timothy P Peters, and Karen Crawley, in print. Abingdon: Routlege.

92. Tranter, Kieran. 2018. Living in Technical Legalities: Law, Technology and Science Fiction. Edinburgh: University of Edinburgh Press.

93. Tulloch, John, and Manuel Alvardo. 1983. Doctor Who: The Unfolding Text. London: Macmillian Press.

94. Tulloch, John, and Henry Jenkins. 1995. Science Fiction Audiences: Watching Doctor Who and Star Trek. London: Routledge.

95. United States Department of Transport, and National Highway Traffic Safety Association. 2016. Federal Automated Vehicles Policy: Accelerating the Next Revolution In Roadway Safety. Washington: United States Department of Transport, National Highway Traffic Safety Association.

96. Vest, Jason P. 2013. Wibbly, Wobbly, Timey, Wimey. Extrapolation 54 (3):304-309.

97. Vismann, Cornelia. 2008. Files: Law and Media Technology. Stanford: Stanford University Press.

98. Walden, Joshua S. 2016. 'He Will Knock Four Times': Fate and the Timey-Wimey Echoes of Beethoven's Fifth Symphony in Doctor Who. Science Fiction Film \& Television 9 (2):181-207.

99. White, Carol J. 2005. Time and Death: Heidegger's Analysis of Finitude. Aldershot: Ashgate.

100. Wither, George. 1635. A Collection of Emblemes, Ancient and Moderne Quickened with Metricall Illustrations, both Morall and Divine: And Disposed into Lotteries London: Henry Taunton.

101. Wolcher, Louis E. 2008. Law's Task: The Tragic Circle of Law, Justice and Human Suffering. Aldershot: Ashgate. 